\title{
Bilateral trade and economic growth of China and India: A comparative study
}

\author{
Sibghat Ullah Farooqui"
}

Department of Commerce, Aligarh Muslim University, Aligarh, Uttar Pradesh, India-202002

\begin{tabular}{|c|c|}
\hline C H R O N I C L E & A B S T RA C T \\
\hline $\begin{array}{l}\text { Article history: } \\
\text { Received October 5, } 2015 \\
\text { Received in revised format } \\
\text { December } 162015 \\
\text { Accepted February } 162016 \\
\text { Available online } \\
\text { February } 162016 \\
\text { Keywords: } \\
\text { Bilateral import-export } \\
\text { Terms of trade (TOT) } \\
\text { Total trade } \\
\text { Gross domestic product (GDP) } \\
\text { Trade openness }\end{array}$ & $\begin{array}{l}\text { This research paper is an attempt to examine the Bilateral Trade and Economic Growth } \\
\text { between China and India, it also gives attention to draw outcome of trade, economic } \\
\text { cooperation in future. They are the fastest growing economies in Asia as well as in the world. } \\
\text { Both economies are classified by many international agencies as emerging markets with } \\
\text { prospective for rapid economy growth. They play an increasingly dominant role in world } \\
\text { economy affair. Especially, this paper investigates the major trends and changes in the Import- } \\
\text { Export, Terms of Trade (TOT), Total Trade, Gross Domestic Product (GDP), and Trade } \\
\text { Openness. By applying various statistical techniques, the results reveal that China has leading } \\
\text { trading partner with India and across the world. The findings are also used to draw policy } \\
\text { implications for future trade and economic co-operation between two Asian developing } \\
\text { economics. The results clearly showed the supremacy of China over India, but India also } \\
\text { elucidates the sign of prominent growing economies in the world. }\end{array}$ \\
\hline
\end{tabular}

\section{Introduction}

Trade is an important fuel of economic growth, China and India are two emerging economies of the world. The growth rates of China and India are estimated at 7.38\% 7.17\% in 2014, respectively. During the period 1980-2014, Average growth domestic product (GDP) growth of China was $9.8 \%$ compared with India's $6.23 \%$ for the same period. China attains the maximum growth of $15.20 \%$ in year 1984 and minimum $3.80 \%$ in 1990 . Out of 35 years from 1980 to 2014 , China growth by more than $10 \%$ in 16 years while India was remained with in only one. India reached an all-time high of $10.26 \%$ in 2010 and a record low of $1.06 \%$ in 1991. India's growth rate was $9-10 \%$ in 4 years, while China in 7 years. Indian Rupee was at 10.34 INR per Chinese Yuan (CNY) on 16 December 2015. Value of Indian Rupees has fallen to 10.18 INR per 1 CNY in 1 Jan 2015.

Bilateral trade between India and China having a potential worth nearly $\$ 100$ billion in year 2015 has created huge and unprecedented opportunities for both countries' business and investors while bringing about a greater stability in the region. Economic cooperation between India and China during the last decade has been a remarkable story, from very modest beginning in 2000-01 of $\$ 2$ billion to $\$ 73.90$ 
billion in 2011. China has become India's largest trade partner and India is China's seventh largest export destination. India and China while encouraging bilateral trade and investment relations, work jointly to establish common negotiating strategies in the international forum. Trade deficit between India and China increased about 34 per cent to USD 48.43 billion in 2014-15 from USD 36.21 billion in the previous fiscal year. Indian government concern on the rising deficit has been discussed, in order to boost exports and address the widening trade deficit with China, the government has taken a number of initiatives to identify specific product lines with export potential, actively taking up issues relating to tariff and non-tariff barriers in bilateral meetings and institutional dialogues.

The trade gap in India narrowed to USD 9.77 billion in October of 2015, compared to a USD 13.5 billion shortfall, a year earlier. It was the lowest trade deficit since February as exports shrank 17.53 percent on year-to-year basis while imports went down 21.15 percent. From April to October, sales declined 17.62 percent and purchases decreased 15.17 percent. Balance of Trade in India averaged 2043.65 USD Million from 1957 until 2015, reaching an all-time high of 258.90 USD Million in March of 1977 and a record low of -20210.90 USD Million in October of 2012. Balance of Trade in India is reported by the Ministry of Commerce and Industry, India.

India has been recording sustained trade deficits since 1980 mainly due to the high growth of imports, particularly of crude oil, gold and silver. Export growth has been a major component supporting China's rapid economic expansion. Exports of goods and services constitute 30\% of GDP. China major exports are: electromechanical products (57 percent of total exports) and labour intensive products like clothing, textiles, footwear, furniture, plastic products, bags and toys (20 percent). In recent years, the exports of high tech products have been also growing and in 2012 accounted for 29 percent of total exports. China's main export partners are the United States (17 percent), European Union (16 percent), Asian (10 percent), Japan (7 percent) and South Korea while India Exports in India decreased 17.53 percent year-on-year to 21352.79 USD Million in October of 2015. Exports in India averaged 4426.08 USD Million from 1957 until 2015, reaching an all-time high of 30541.44 USD Million in March of 2013 and a record low of 59.01 USD Million in June of 1958. Exports in India are reported by the Ministry of Commerce and Industry, India. In recent years, India has become one of the biggest refined product exporters in Asia with petroleum accounting for around 20 percent of total exports. The country also exports engineering goods (19 percent of the total shipments), chemical and pharmaceutical products (14 percent), gems and jewellery (14 percent), agricultural and allied products (10 percent) and textiles and clothing (10 percent). India's main export partners are: United Arab Emirates (12.1 percent of the total exports), the United States (12 percent), Singapore (4.5 percent), China (4.5 percent), Hong Kong ( 4 percent) and Netherlands (3.5 percent). Fig. 1 shows the Import of china and India for the last 33 years. In 1982, the import of china and India were 18900 and 17517.5 US \$ (millions) and jumped to 1808720 and 405122 US \$ (millions). Fig. 2 shows the comparative export between India and China during the period 1982 to 2014 in US \$ at current prices and current exchange rates in millions which clearly shows the expanding export of China in the world market as compared with India. In 1982, China exported 23637 millions US \$ (millions) and reached 2243761.3 US \$ (millions) in 2014 and comparatively India's export moved from 12159.03 US \$ (millions) to 329633 US Dollar. The terms of trade of China reached at 124.0525 in 2014 which at the highest in 2007 at 135.5943 as compared with India only moved at 81.36635 (see Fig. 3). The GDP of India was worth 2041085 US \$ (millions) in 2014. The GDP value of India represents 3.33 percent of the world economy. The GDP of China reached at 10066674.21 in 2014 which very large as compared with India (See Fig. 4). The trade openness of China are highly appreciated ruined at 40.25 percent as compared with India to 35.99 percent which were 14.40 and 14.74 percent in 1982 clearly seems in Fig. 5. The GDP growth rate also reveals that stability of China growth are more sustain year by year, during 2014 China and India growth rate were 7.4 and 5.4 percent (See Fig. 6), respectively. The Bilateral trade between India and china in terms of export and import shows that export to china moved from 14.6 to 11966.7 US\$ millions and simultaneously import from china expand from 118.9 to 60442.2 US\$ millions during 1987 to 2014 See Fig. 7. 


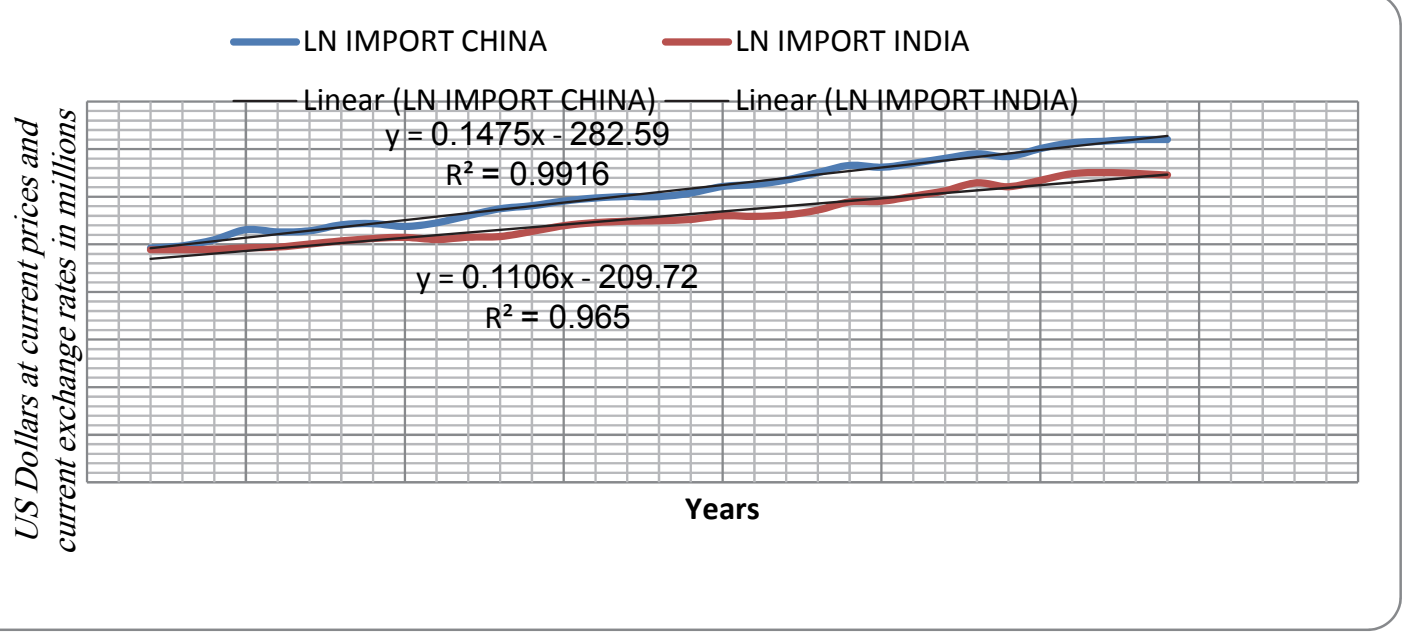

Fig. 1. The Import of India and China for the period from 1982 to 2014

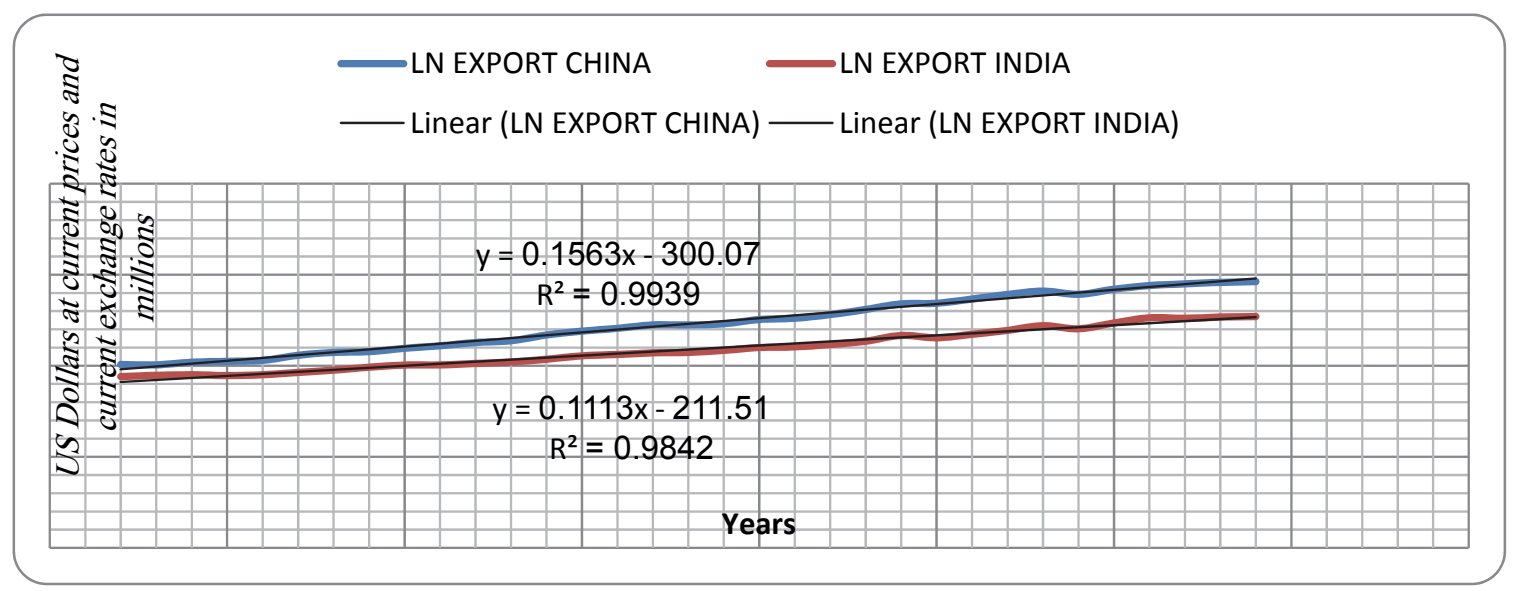

Fig. 2. The Export of India and China for the period from 1982 to 2014

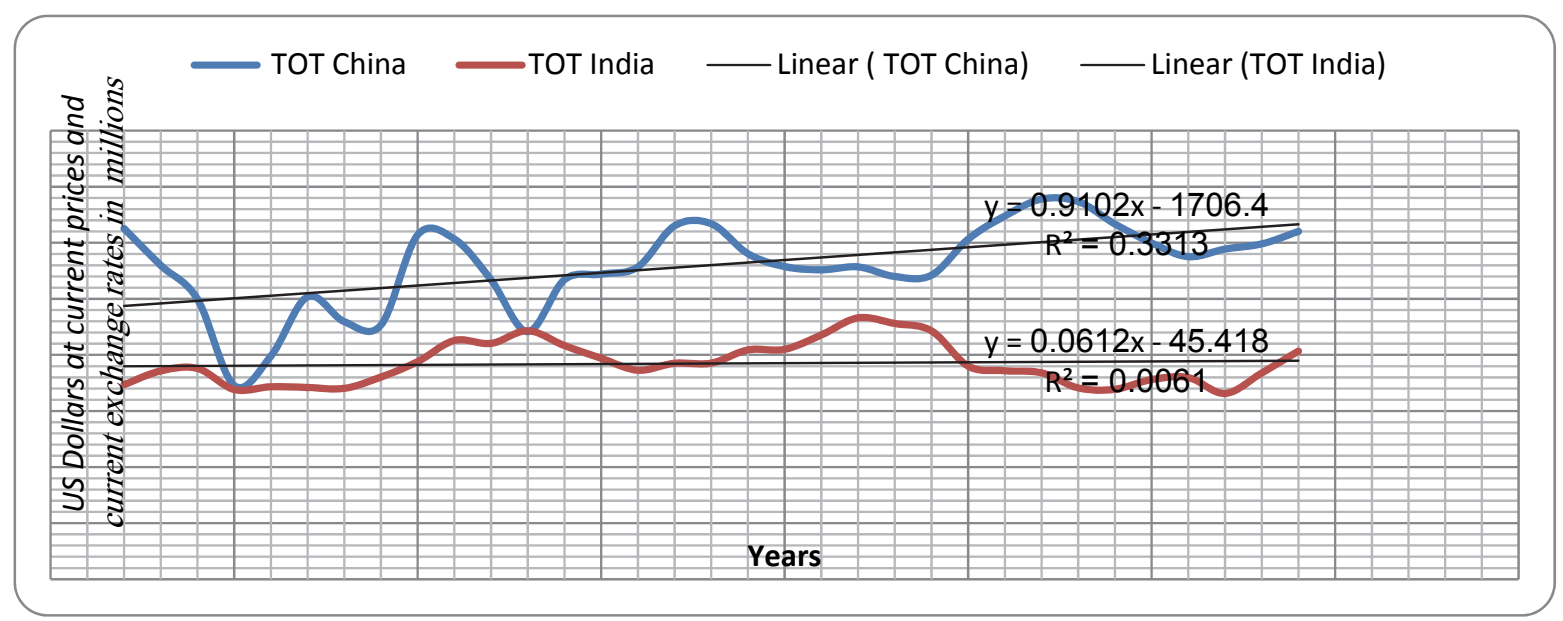

Fig. 3. The Term of Trade (TOT) Import of India and China for the period from 1982 to 2014 


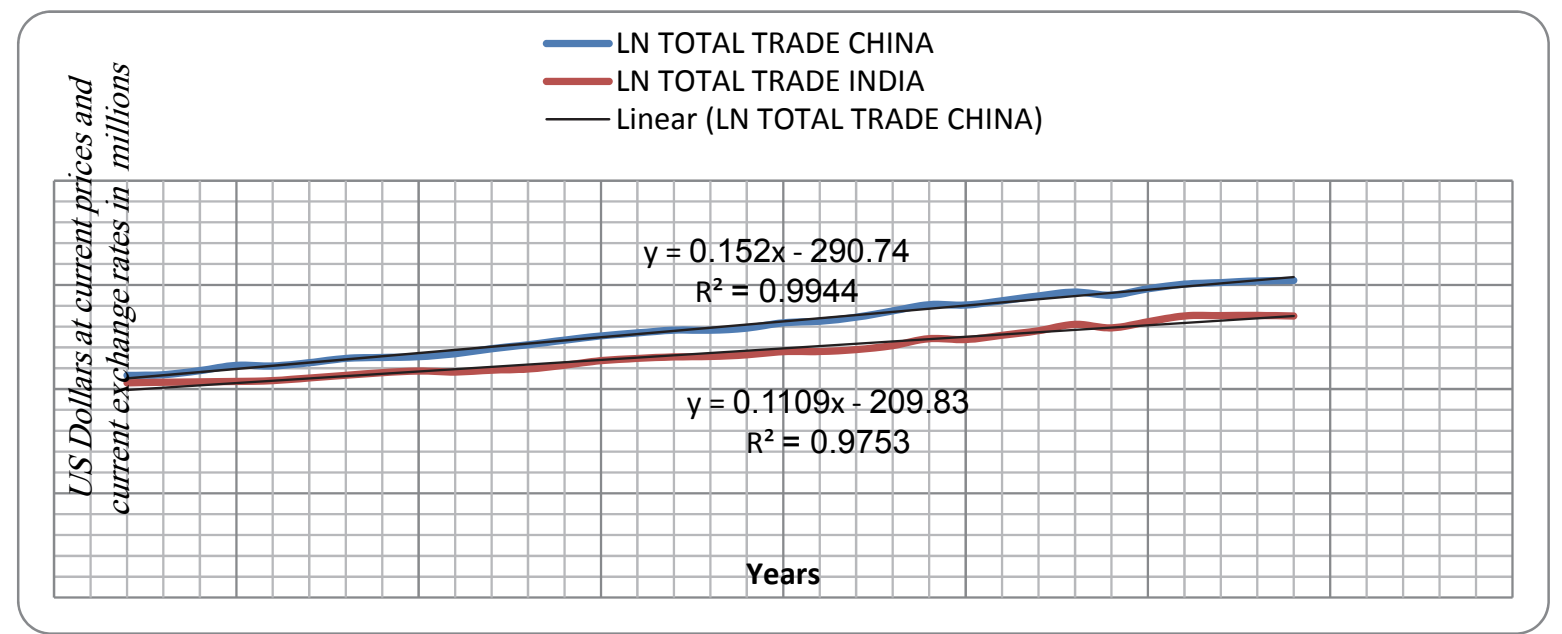

Fig. 4. The Total Trade of India and China for the period from 1982 to 2014

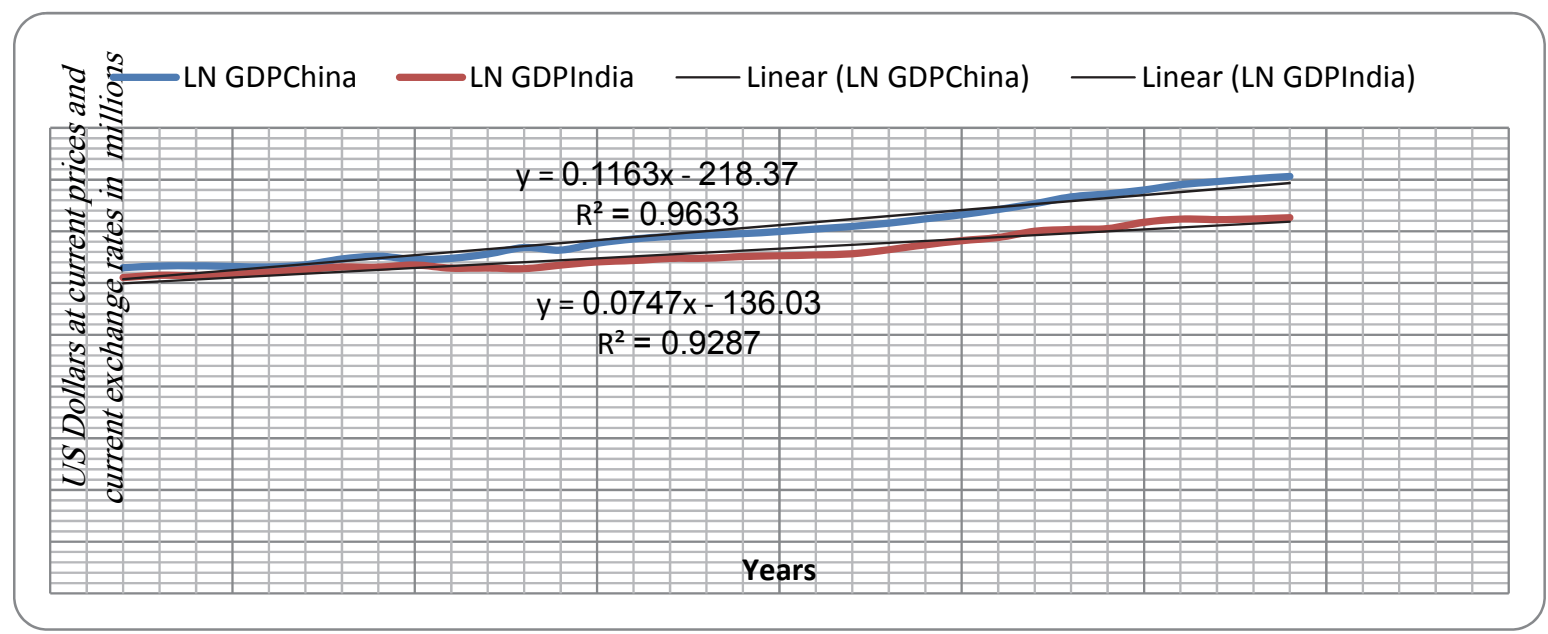

Fig. 5. The Gross Domestic Product (GDP) of India and China for the period from 1982 to 2014

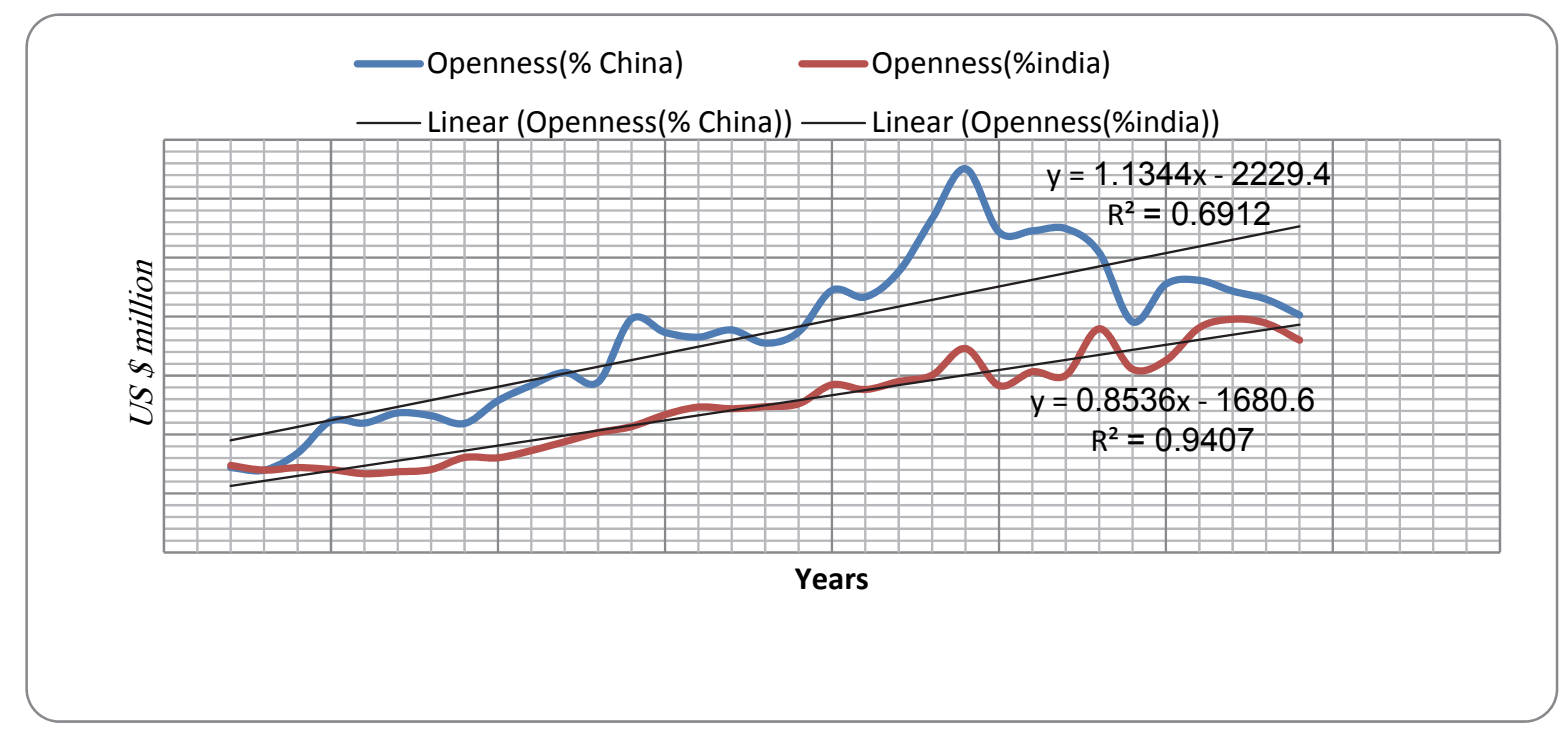

Fig. 6. The Trade Openness of India and China for the period from 1982 to 2014 


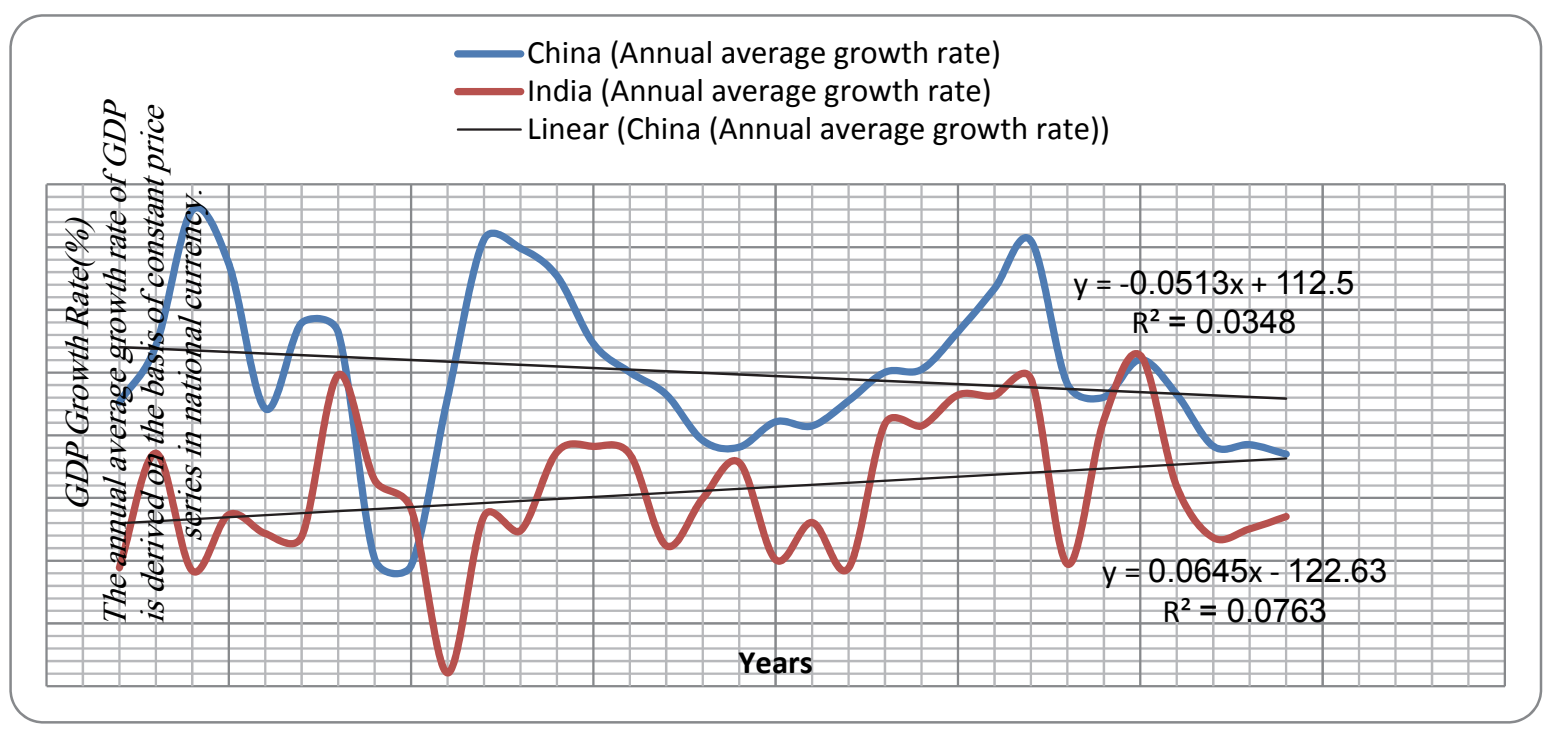

Fig. 7. The Gross Domestic Product (Growth Rate \%) of India and China for the period from 1982 to 2014

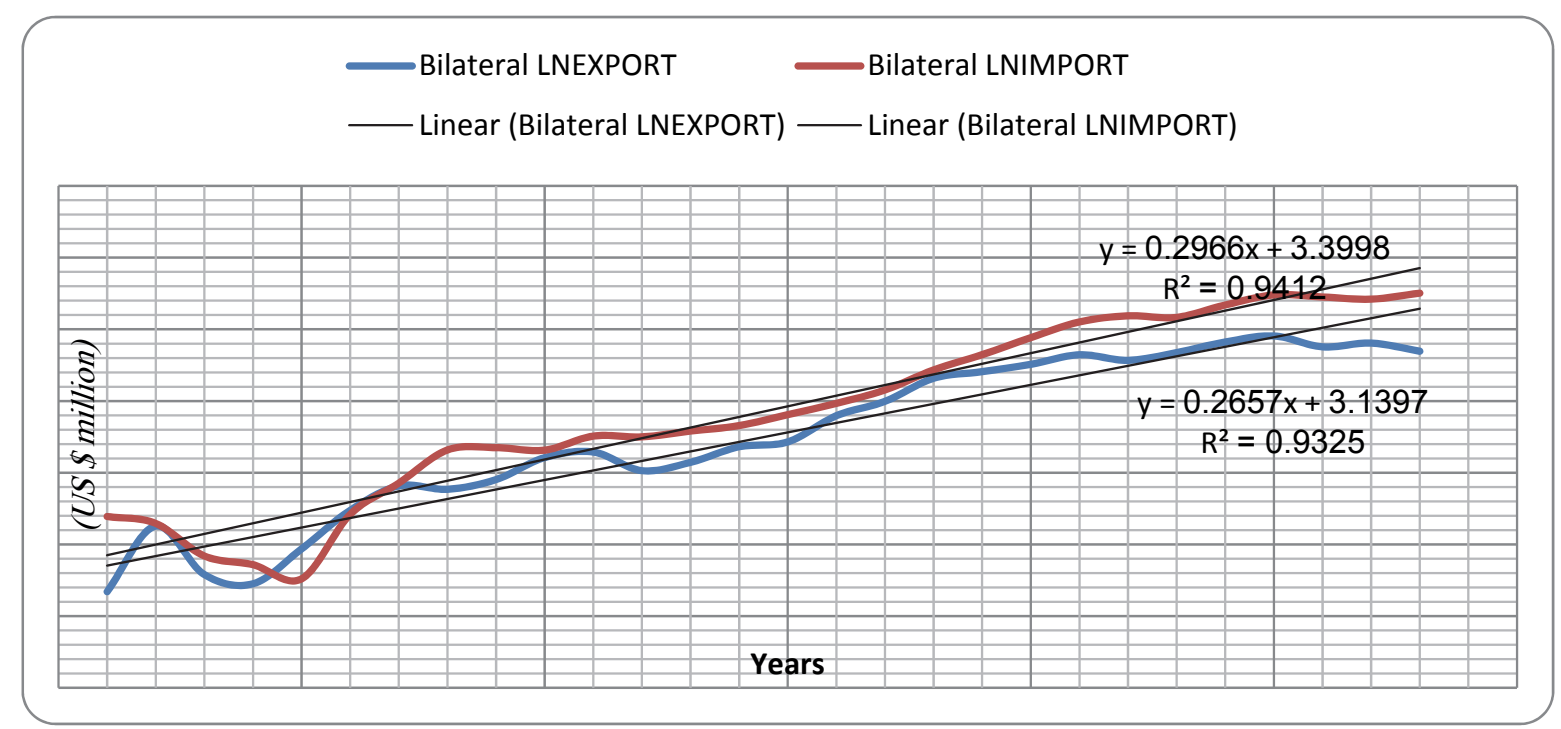

Fig. 8. The Export to china and Import from china for the period from 1982 to 2014

\section{Review of Literature}

Jinping (2003) measured revealed comparative advantage (RCA) of various industries in China and other East Asian Economies over the period of 1980-1997, and measured the trade complementarities between China and other East Asian economies for the same period. The empirical results showed that China had not had RCA in machinery compared with Japan, Taiwan, South Korea and Singapore. China's imports are complementary to the exports of Taiwan, South Korea, Indonesia, Malaysia and Thailand, while the complementarities between China's exports and the imports of these economies are not obvious. Singh (2005) investigated that booming bilateral trade has come to be the strongest pillar of China-India rapprochement. This is not only since overtaken the pace of political confidencebuilding but also has a substantial impact on their mutual perceptions. The boom in trade has also introduced new trends. The two states are no longer only recipients on foreign direct investment but have entered into a new phase of being investors, both mutually as in other regions. In this new context, 
the increasing deficit in the energy sector and the competition to capture new markets present major challenges to sustaining this boom in their bilateral trade. Rajan (2005) explained in his study that the Global environment was characterized by an intense Global Race for FDI. Hence, Alternatively, intervention must concentrated on refining the host country's overall abilities to gain from FDI by contributing the quality of the employee and infrastructure in a country, contribute to local skills, technology and domestic learning, and trying to reach a stable and conducive overall macroeconomic conditions. Mohanty and Chaturvedi (2005) examined that China and India had emerged as highly dynamic economies during the last few years. In Asia, their growth and economic expansion has generated its own complementarities. The paper has empirically revealed that surge in the exports of these two countries have significantly contributed to their overall economic growth. India and China have made steady progress in frontier technologies such as ICT and biotechnology, and provide easy access towards technologies to LDCs and other developing countries. Kapur (2005) observed that the economic reforms of 1991 opened the Indian economy for foreign players. For FDIs, India has now become burning destination because of its vast potential. The Indian investment setting is constantly changing and the country has become the third most preferred destination for investors after China and US. Desai (2005) studied that the contrast between the economic performance of China and India and its proximate causes. But there were also a lot of similarities between two countries in the path to modernization and the future prospects for their economies. There have been also political similarities and contrasts between the two in terms of their 20th century histories and 21 st century challenges. The study argued that India remains a soft state, a consensual polity, and not capable of sustained growth at the sort of rates which China had attained. Batra and Khan (2005) in their paper revealed comparative advantage had analyzed at both the two and six digit level of HS classification for both India and China. The analysis reveals that the pattern of comparative advantage varies at different levels of commodity disaggregation. Sectors that rank among the top ten according to the value of the index of RCA are not necessarily capable of keeping their positions. For China, other made textiles, sets, worn clothing is so positioned. Concurrently, some sectors where either of the countries may be disadvantageously placed at the combined level but may enjoy comparative advantage at the ingredient commodity level. Wu and Zhou (2006) studied bilateral trade between China and India and examined and compared international trade and between the two economies and drew implications for trade and economic cooperation between China and India in the future. The study investigated the major trends of changes in the bilateral trade between the two countries, and explored issues associated with trade intensity, intraindustry trade and comparative advantages in the two countries. Chakraborty and Nunnenkamp (2006) assessed the economic growth implications of FDI in India. It was found that the growth effects of FDI varied widely across sectors. FDI stocks and output were mutually reinforcing in the manufacturing sector. Most strikingly, they found only transitory effects of FDI on output in the service sector, which engrossed the level of FDI in the post-reform era. Subhajit (2008) tried to shape up the possible effects on a free trade agreement between these trading giants, in addition to a general overview of how trading relation had gone in the last decades and tried to magnify into the fact that whether the proposed FTA agreement between India and China could lead to any welfare gains for India or not. Pillania (2010) illustrated that India and China are among the oldest civilizations of the world with extensive interaction and relationship. They are the fastest growing economies among the major economies of the world. Both have made rapid progress after liberalisation. One of the major events in international trade and economics is the recent fast growth in the bilateral trade. He mentioned that India emerged as one of the top ten trading partners of China. The bilateral trade enhanced the further trade and have significant impacts on worldwide trade and economy. Sahoo (2013) examined the performance of China, in which exports industries enjoys comparative advantage, including textiles and textile articles, chemical products, machinery, mechanical appliances, footwear, headwear, hides and skins, whereas India is losing market share. However, India is the leading exporter of essential and basic commodities to its neighbouring countries. China's policy for trade was also encouraging for South Asian countries, such as inviting traders to China for exhibitions, assurance of the provision of advanced technology and willingness to build capacity, training local people, facilitating trade, investing in crucial industries, and assisting local projects, particularly in infrastructure. Dutt and 
According to Panwar (2014) India and China were the two largest countries in the world in terms of population, both are also the fastest growing economies in the world. Booming trade relations between India and China are of at the starting point, more or less matched with the onset of contented levels of economic development in both countries. India and China jointly are home to the world's largest pools of skilful human resources, and there is a general accord that these two countries will continue to be the devices of global economic growth in the 21 st century. Increasing bilateral trade has come to be the strongest pillar of China-India rapprochement. Kumari and Malhotra (2014) studied that the trade-led growth theory has received considerable attention over the time period with large amount of literature devoted to analyse it empirically particularly in case of exported growth hypothesis. The study concludes that China performed better than India. The difference in performance between India and China was not simply because of timings of changes in policies but the speed of reforms, implementation of policies and nature of political governance also mattered. Chellasamy and Menon (2015) analyzed the impact of foreign trade on GDP of India using annual data during period (from 2004 to 2014). The analysis revealed that there was a significant impact of foreign trade on GDP. Import contributes positively GDP while, Export input were unenthusiastic.

\section{Research gap}

The review of literature reveals that numerous studies have been conducted to assess Trade relation between India and China. Moreover, several research articles have raised the significant issues with regard to FDI and growth as well. Most of the prior studies that had discussed the relation between India and China were theoretical in nature. There are few empirical evidences available that have investigated the trade relation between these two countries on the bases of single trade indices (Export, Import, FDI, GDP, RCA etc.) or adequately explored. Therefore, this study makes an earnest attempt to fill the gap by incorporating macro-economic variables and Trade related indices. However, this study goes a step further to examine the impact of bilateral trade flows between India and China.

\subsection{Objectives}

$>$ To study the overall Export and Import of India and China,

$>$ To evaluate the Terms of Trade (TOT), Total Trade, Gross Domestic Product (GDP), Trade Openness (\%) of India and China,

$>$ To study the GDP (Growth Rate) of India and China,

$>$ To examine the Bilateral Trade between India and China in terms of Export and Import.

\subsection{Hypotheses}

$\mathrm{H}_{01}$ (Null Hypothesis) $=$ There is no significant difference between the Import of India and China.

$\mathrm{H}_{02}$ (Null Hypothesis) $=$ There is no significant difference between the Export of India and China.

$\mathrm{H}_{03}$ (Null Hypothesis) $=$ There is no significant difference between the Terms of Trade (TOT) of India and China.

$\mathrm{H}_{04}$ (Null Hypothesis) $=$ There is no significant difference between the Total Trade of India and China.

$\mathrm{H}_{05}$ (Null Hypothesis) $=$ There is no significant difference between the Gross Domestic Product (GDP) of India and China.

$\mathrm{H}_{06}$ (Null Hypothesis) $=$ There is no significant difference between the Trade Openness (\%) of India and China.

$\mathrm{H}_{07}$ (Null Hypothesis) $=$ There is no significant difference between the GDP (Growth Rate) of India and China.

$\mathrm{H}_{08}$ (Null Hypothesis) $=$ There is no significant difference between Export to China and Import from China.

\subsection{Research methodology}

To accomplish the aforementioned objectives secondary data were collected from various sources such as periodicals, journals, relevant books, research papers, published theses, articles, news dailies and 
different websites for better referencing. The publications and review bulletins of regulatory bodies and institutions, such as RBI, World Bank, UNCTAD, annual reports and handbook of statistics on Indian economy, Department of Industrial Policy and Promotion (DIPP), SIA newsletter, Fact sheets, books and journals etc. for the purpose of analyzing the data Independent t-test and f-test are undertaken.

\subsection{Analysis and interpretation}

$\mathrm{H}_{01}$ (Null Hypothesis) $=$ There is no significant difference between the Import of India and China.

This hypothesis deals with the difference between the Import of India and China. The analysis given in Table 1 and Table 2 explained that the Levene's test for equality of variances indicates variances for the Import of India and China did not differ significantly from each other ( $\mathrm{P}$-value=.053). Therefore equal variance results are used for t-test. The mean for the Import of India is 11.1616 and the mean for the Import of china is 12.1953 which show significant difference between both the countries. The standard deviation for India and China are 1.08824 and 1.43270, respectively. The mean did differ significantly with $t$-value 3.301 and also the $P$-value is 0.002 which is less than 0.05 and leads to rejection of Null Hypothesis. Hence, there is a significant difference between the Import of India and China.

$\mathrm{H}_{02}$ (Null Hypothesis) $=$ There is no significant difference between the Export of India and China.

Table 1 indicates that thirty three years of Export had a mean of 10.8946 for the India, The thirty three years of Export had a mean of 12.2991 for the China, but the standard deviation for the India is 1.08494 and for the China 1.51641 and the mean did differ significantly with t- value 4.327 (Table 2). The sigvalue (2-tailed) is 0.000 and this value is less than 0.05 which leads to the conclusion that the difference is statistically significant. Levene's test for equality of variances indicates variances for India and China Export do differ significantly from each other $(\mathrm{P}-\mathrm{value}=.027)$. Therefore unequal variance results are used for t-test. Therefore, the Null Hypothesis is rejected. Hence there is a ignificance difference between Export of India and China. The result of the analysis clarified that Export of China has significantly increased.

$\mathrm{H}_{03}$ (Null Hypothesis) $=$ There is no significant difference between the Terms of Trade (TOT) of India and China.

Table 1 and Table 2 indicate the result of third hypothesis that examines the difference between the Terms of Trade (TOT) of India and China. The mean for the India is 76.9225 and the mean for the China is 112.0623 which are very high. The descriptive statistics also show the standard deviation between the Terms of Trade (TOT) of India and China. The standard deviation for the India is 7.58734 and for the China is 15.29125 . The $t$-value is 11.825 and had the $P$-value is 0.000 which is less than 0.05 and leads to statistically significant. Levene's test for equality of variances indicates variances for India and China Terms of Trade (TOT) do differ significantly from each other (P-value=.000). Therefore, unequal variance results are more powerful for t-test. Therefore Null Hypothesis is rejected. Hence, it is concluded that there is significant difference between the Terms of Trade (TOT) of India and China.

$\mathrm{H}_{0} 4$ (Null Hypothesis) $=$ There is no significant difference between the Total Trade of India and China. Table 1and Table 2 illustrate the results of this hypothesis that examines the difference between the Total Trade of India and China. Levene's test for equality of variances indicates variances for the Total Trade of India and China did differ significantly from each other (P-value=.037). Therefore unequal variance results are used for t-test. The mean for the India's Total Trade is 11.7312 and for the China had 12.9444 and the standard deviation for the India and China is $(1.08577 \mathrm{~V} / \mathrm{s} 1.47382)$ and $t$-value is 3.807. The $\mathrm{p}$ - value is at 0.000 which is less than 0.05 indicates that the mean did significantly differ 
statistically. The Null Hypothesis is rejected. Hence, there is significant difference between the Total Trade of India and China.

$\mathrm{H}_{05}$ (Null Hypothesis) $=$ There is no significant difference between the Gross Domestic Product (GDP) of India and China.

Table 1 and Table 2 show the difference between the GDP of India and China. In description statistics the mean for the India is 13.1806 and for the China is 14.0061 . The thirty three years of data are used for the analysis. Levene's test for equality of variances indicates variances for India and China Gross Domestic Product (GDP) do differ significantly from each other (P-value=.012). Therefore, equal variance results are used for t-test. The $t$-value is 3.464 and p-value is 0.001 . Since this value is less than 0.05 which indicates the mean of GDP significantly differs statistically, which lead to Rejection of Null Hypothesis. Hence, there is significant difference between the Gross Domestic Product (GDP) of India and China.

$\mathrm{H}_{0} 6$ (Null Hypothesis) $=$ There is no significant difference between the Trade Openness (\%) of India and China.

Table 1 and Table 2 give an insight of statistical analysis of India and China Trade Openness. Levene's test for equality of variances indicates variances for India and China Trade Openness did differ significantly from each other ( $\mathrm{P}$-value=.024). Therefore unequal variance results are used for t-test. Descriptive statistics revealed that the mean for the India is 24.9435 and the mean for the China is 37.1438 with standard deviation for the India is 8.51050 and for the China 13.19367 and the mean did differ significantly at the $t$-value 4.464 and also shows the p-value is 0.000 . This value is less 0.05 . Because of this, it can be conclude that there is a statistically significant difference between the Trade Openness (\%) of India and China, which leads to rejection of Null Hypothesis. Hence there is significant difference between the Trade Openness (\%) of India and China.

$\mathrm{H}_{0} 7$ (Null Hypothesis) $=$ There is no significant difference between the GDP (Growth Rate) of India and China.

This hypothesis examined the differences between GDP (Growth Rate) of India and China. Table 1 and 2 explained the results. The mean for the India is 6.2277 and for the China is 9.9922 which is high. The standard deviation for the India is 2.25726 and the mean for the China is 2.65935. Levene's test for equality of variances indicates variances for India and China GDP growth rate do not differ significantly from each other $(\mathrm{P}$-value $=.689)$. Therefore equal variance results are more powerful for $\mathrm{t}$-test.

The Independent samples analysis gives the $t$-statistic is 6.200 and p-value is 0.000 which is less than 0.05 and leads to conclusion that the difference is statistically significant. The Null hypothesis is rejected. The performances of China in terms of GDP growth rate are much more growing as compared to India. Hence, there is significant difference between the GDP (Growth Rate) of India and China.

$\mathrm{H}_{0} 8$ (Null Hypothesis) $=$ There is no significant difference between Export to China and Import from China.

The results of analysis explored in Table 3, where twenty eight years of data of Bilateral Export-Import are undertaken. The mean for the India's Export to China is 6.9929 and for the India's Import from China is 7.6964. The Standard deviation for the India's Export to China is 2.25387 and for the India's Import from China are 2.52080. Levene's test for equality of variances indicates variances for Export to China and Import from China did not differ significantly from each other (P-value $=.568)$. Therefore equal variance results are used for t-test. Table 4 shows that the t-test is further undertaken which gives the t-value -1.101 and sig-value (2-tailed) is 0.276 which is more than 0.05 therefore it is statistically 
insignificant and leads to acceptance of Null Hypothesis. Hence there is no significance difference between Export to China and Import from China.

\section{Table 1}

Exhibits the Descriptive Statistics of Comparison of Import, Export Terms of trade, Total Trade, GDP, Openness Percent, GDP growth rate of India and China

\begin{tabular}{|c|c|c|c|c|c|c|c|c|c|c|c|c|c|c|}
\hline & \multicolumn{2}{|c|}{$\begin{array}{l}\text { LN IMPORT } \\
\text { GROUP }\end{array}$} & \multicolumn{2}{|c|}{$\begin{array}{l}\text { LN EXPORT } \\
\text { GROUP }\end{array}$} & \multicolumn{2}{|c|}{$\begin{array}{c}\text { TOT } \\
\text { GROUP }\end{array}$} & $\begin{array}{r}\text { LN T } \\
\text { TR } \\
\text { GR }\end{array}$ & $\begin{array}{l}\text { DTAL } \\
\text { ADE } \\
\text { DUP }\end{array}$ & $\begin{array}{l}\mathrm{LN} \\
\mathrm{GRC}\end{array}$ & $\begin{array}{l}\text { GDP } \\
\text { DUP }\end{array}$ & \multicolumn{2}{|c|}{$\begin{array}{l}\text { OPENNESS } \\
\text { PERCENT }\end{array}$} & \multicolumn{2}{|c|}{$\begin{array}{c}\text { GDP GROWTH } \\
\text { RATE } \\
\text { GROUP }\end{array}$} \\
\hline & CHINA & INDIA & CHINA & INDIA & CHINA & INDIA & CHINA & INDIA & CHINA & INDIA & CHINA & INDIA & CHINA & INDIA \\
\hline $\mathrm{N}$ & 33 & 33 & 33 & 33 & 33 & 33 & 33 & 33 & 33 & 33 & 33 & 33 & 33 & 33 \\
\hline Mean & 12.1953 & 11.1616 & 12.2991 & 10.8946 & 112.0623 & 76.9225 & 12.9444 & 11.7312 & 14.0061 & 13.1806 & 37.1438 & 24.9435 & 9.9922 & 6.2277 \\
\hline Std. Deviation & 1.43270 & 1.08824 & 1.51641 & 1.08494 & 15.29125 & 7.58734 & 1.47382 & 1.08577 & 1.14584 & .74934 & 13.19367 & 8.51050 & 2.65935 & 2.25726 \\
\hline $\begin{array}{l}\text { Std. Error } \\
\text { Mean }\end{array}$ & .24940 & .18944 & .26397 & .18886 & 2.66187 & 1.32079 & .25656 & .18901 & .19946 & .13044 & 2.29672 & 1.48149 & .46293 & .39294 \\
\hline
\end{tabular}

\section{Table 2}

The results of $\mathrm{F}$ and t-statistics of comparison of Import, Export Terms of trade, Total Trade, GDP, Openness Percent, GDP growth rate of India and China

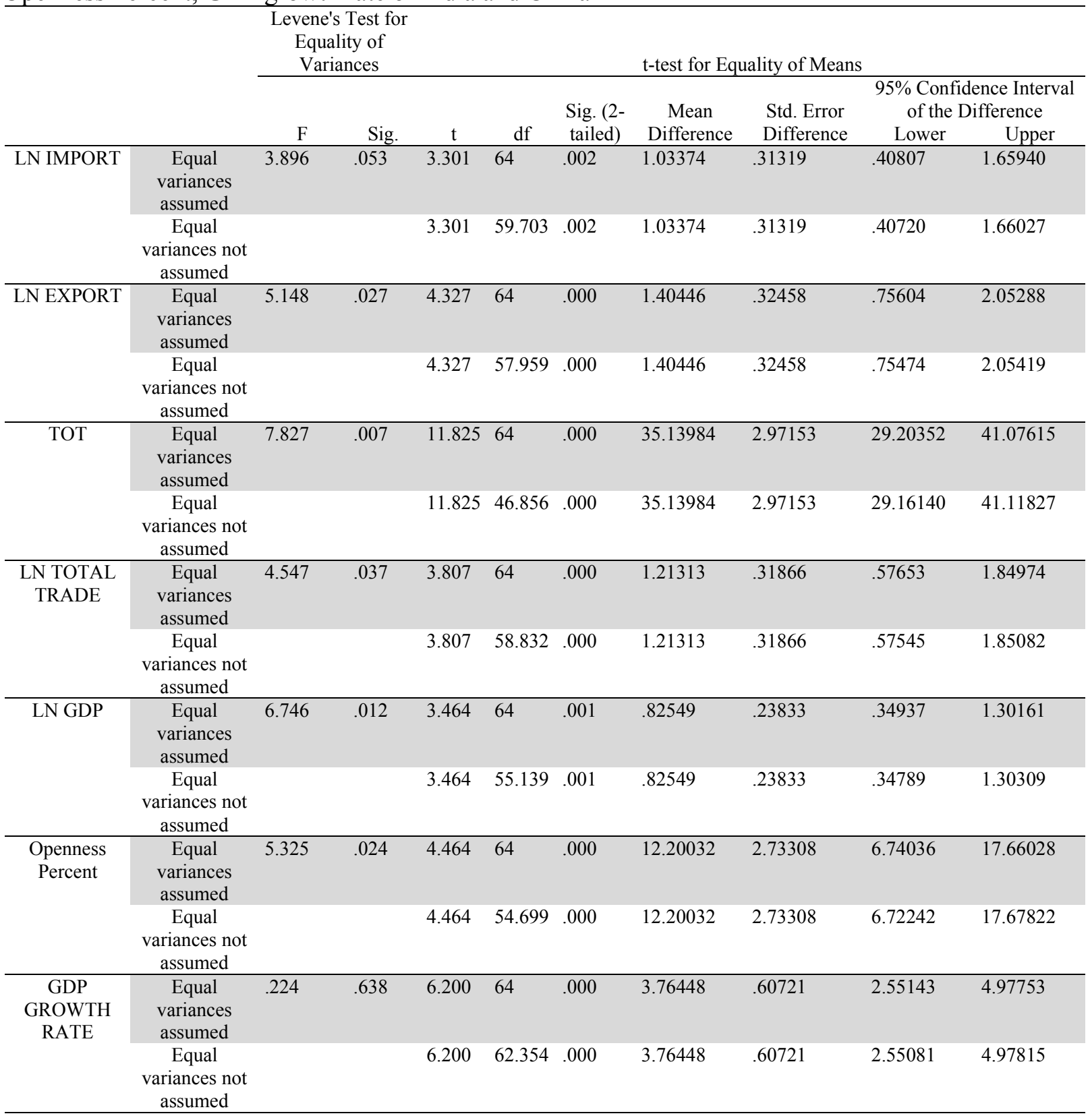


Table 3

Descriptive statistics of comparison of bilateral Export-Import of India to China

\begin{tabular}{|c|c|c|}
\hline & \multicolumn{2}{|c|}{ LN BILATERAL EXPORT-IMPORT } \\
\hline & & \\
\hline & EXPORT TO CHINA & IMPORT FROM CHINA \\
\hline $\mathrm{N}$ & 28 & 28 \\
\hline Mean & 6.9929 & 7.6964 \\
\hline Std. Deviation & 2.25387 & 2.52080 \\
\hline Std. Error Mean & .42594 & .47639 \\
\hline
\end{tabular}

Table 4

Reveals the F and t-statistics of comparison of bilateral Export-Import of India to China

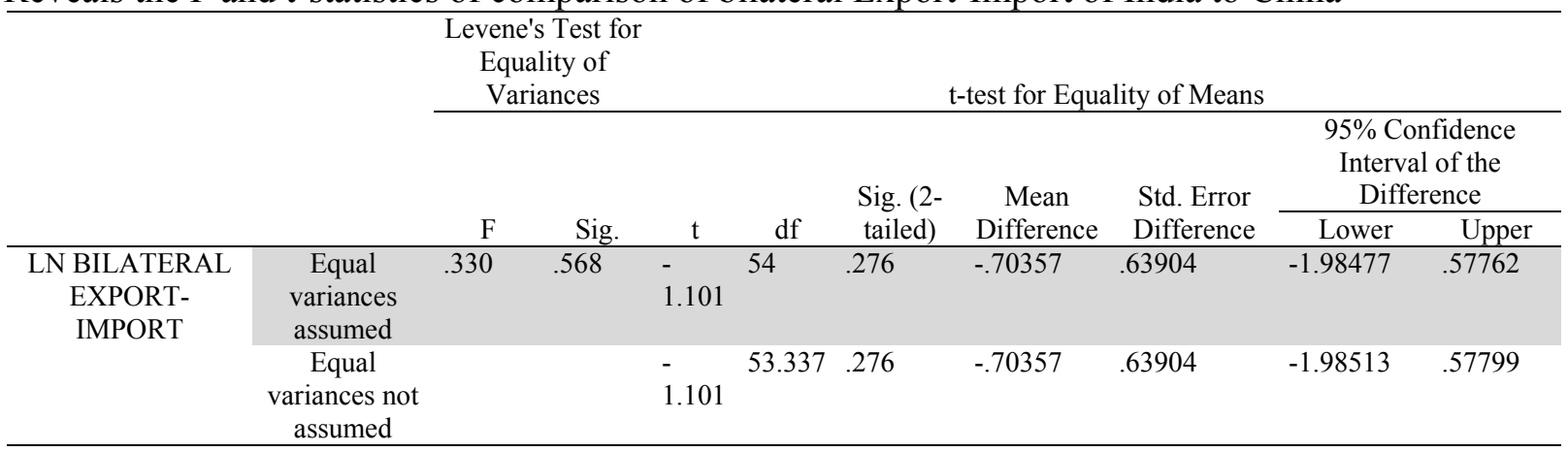

\section{Conclusion}

This empirical study have shown that bilateral trade between India and china were significant for economic growth of both countries. The results reveal that trade between china and India has significant difference in terms of Import, Export, Term of Trade, Total trade, GDP trade openness and GDP growth rate. China has far away from India and opened all roads for the business. The TOT results also have shown that china was getting more capital from its export and more influence of trade on domestic activities and makes country stronger as compared to India.

The Bilateral trade between India and china did not show significant difference, but clearly exhibit that china was more focussed on export to India. The bilateral trade between these two countries was unfavourable to India and also balance of trade was unfavourable to India. The study have concluded that China performed better compared with India. The difference in performance between India and China is not simply because of timing of changes in policies but the speed of reforms, implementation of policies and nature of political governance also mattered.

\section{References}

Batra, A., \& Khan, Z. (2005). Revealed comparative advantage: An analysis for India and China. Indian Council for Research on International Economic Relations, Working Paper, 168, 1-85.

Chakraborty, C., \& Nunnenkamp, P. (2006). Economic reforms, foreign direct investment and its economic effects in India (No. 1272). Kieler Arbeitspapiere.

Chellasamy, P., \& Menon, A. A. (2015). Impact of foreign trade on Indian economic growth-with respect to Gross Domestic Product (GDP). ZENITH International Journal of Business Economics \& Management Research, 5(2), 67-72.

Desai, M. (2005). India and China: an essay in comparative political economy. In India's and China's Recent Experience with Reform and Growth(pp. 1-22). Palgrave Macmillan UK.

Dutt, M. S., \& Panwar, (2014). An analysis of Indo-China trade trends (past \& projected) in the postliberalisation era. 
Jinping, Y. (2003). Comparative Advantage and Trade Complementarity between China and Other Asian Economies[J]. World Economy, 5, 33-40.

Kapur, S. (2005). FDI in India: recent Trends and Prospect, Treasury Management, the ICFAI University Press, August.

Kumari, D., \& Malhotra, (2014) N. Trade-Led Growth in India and China: A Comparative Analysis.

Mohanty, S. K., \& Chaturvedi, S. (2005). Emergence of China and India in the New Millennium: Will it Facilitate Market Access for LDCs and Developing Countries? (No. 22120).

Pillania, R. K. (2010). Indo-China Trade: trends, Composition and Future.Journal of Applied Economic Sciences, 5(2 (12)/Summer2010), 129-137.

Rajan, R. S (2005) "Foreign Direct Investment and the Internationalization of Production in the Asia Pacific Region Issues and Policy Conundrums", Asia Pacific Trade and Investment Review, 1stApril.

Sahoo, P. (2013). The Growing Dominance of China in South Asia: An Indian Perspective. The International Trade Journal, 27(2), 111-141.

Singh, S. (2005). China-India Bilateral Trade:. Strong Fundamentals, Bright Future. China Perspectives, (62).

Subhajit, S. (2008). Effects of Free Trade Agreement on Indo-China Trade.Available at SSRN 1152134.

Wu, Y., \& Zhou, Z. (2006). Changing bilateral trade between China and India

\section{Websites}

India and china GDP', retrieved from http://statisticstimes.com/economy/china-vs-india-gdp.php 'India and china trade centre', retrieved from http://www.ictc.org.in/

'India-China trade deficit swells $34 \%$ to $\$ 48$ billion', retrieved from

http:/www.thehindu.com/news/national/indiachina-trade-deficit-swells-34-to-48billion/article7201545.ece

'Balance of Trade', retrieved from http://www.tradingeconomics.com/india/balance-of-trade. 